\title{
Picoplankton diversity in the South-East Pacific Ocean from cultures
}

\author{
F. Le Gall ${ }^{1}$, F. Rigaut-Jalabert ${ }^{1}$, D. Marie ${ }^{1}$, L. Garczarek ${ }^{1}$, M. Viprey ${ }^{1}$, A. Gobet ${ }^{1,2}$, and D. Vaulot ${ }^{1}$ \\ ${ }^{1}$ Station Biologique de Roscoff, UMR 7144, CNRS et Université Pierre et Marie Curie, Place G. Tessier, 29682, Roscoff, \\ France \\ ${ }^{2}$ present address: Max Planck Institute for Marine Microbiology, Celsius Strasse 1, 28359 Bremen, Germany
}

Received: 4 July 2007 - Published in Biogeosciences Discuss.: 7 August 2007

Revised: 3 January 2008 - Accepted: 18 January 2008 - Published: 15 February 2008

\begin{abstract}
In late 2004, the BIOSOPE cruise sailed between the equatorial influenced waters off the Marquesas Islands and the nutrient enriched waters of the Chilean upwelling. Along the way, it explored the Southeast Pacific gyre centred around Easter Island, which is probably the most oligotrophic oceanic region on earth. During this cruise, we undertook a vigorous effort to isolate novel photosynthetic picoplanktonic eukaryotes. Two strategies were attempted on board: enrichment of filtered samples with culture medium and sorting of specific populations by flow cytometry based on size and chlorophyll fluorescence. Over 1900 pre-cultures were started and then further purified by flow cytometry, serial dilution or pipette isolation to yield a total of 212 strains. These strains were characterized morphologically and for more than $50 \%$ of them, genetically, through partial sequencing of the $18 \mathrm{~S}$ rRNA gene.

Among the characterized strains, the largest number belongs to stramenopiles (Heterokontophyta) with a record of 38 strains belonging to the species Pelagomonas calceolata (Pelagophyceae). Strains from the recently described genera Bolidomonas and Florenciella have been re-isolated for the first time since their description. Two other abundant groups are the Chlorophyta, especially Prasinophyceae, and the Haptophyta, especially the genera Phaeocystis and Emiliania. A limited number of heterotrophic flagellates have also been isolated, all of them belonging to groups containing known species. Finally, over a dozen of unicellular cyanobacterial Synechococcus strains have been obtained, some forming unusual short chains.

Overall our strategy was quite successful since it allowed us to isolate a large number of picoplankton strains. Still it failed in two respects. First, apparently very few novel taxa have been obtained. One set of strains is related to Prasino-
\end{abstract}

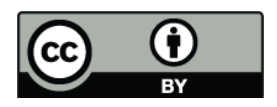

Correspondence to: D. Vaulot (vaulot@sb-roscoff.fr) derma coloniale (Prasinococcales, Prasinophyceae) but their sequences are sufficiently different from the latter to probably belong to a new genus or species. The sequences of two other strains, unfortunately later lost, were phylogenetically affiliated to stramenopile environmental sequences, probably corresponding to a new algal class. Second, very few strains have been obtained from the very oligotrophic central gyre itself. In order to be successful, future work in similar waters should probably combine flow cytometry sorting with culture media and cultivation approaches specifically developed for oligotrophic water species.

\section{Introduction}

Although the existence of very small algal cells had been known for more than 150 years (Nägeli, 1849), it was only 30 years ago, that their importance in marine waters was recognized (Johnson and Sieburth, 1982; Waterbury et al., 1979), leading to the definition of picoplankton, designating cells with size between 0.2 and $2 \mu \mathrm{m}$ (Sieburth et al., 1978). It was soon realized that a significant fraction of photosynthetic biomass and primary production could be attributed to these tiny cells (Li et al., 1983; Platt et al., 1983). This small size fraction was found to be more important as chlorophyll concentration decreased, i.e. as the degree of oligotrophy increased (Herbland et al., 1985). Within photosynthetic picoplankton, prokaryotes appeared early on as much less diversified than eukaryotes since they are dominated by only two major cyanobacteria genera: Prochlorococcus and Synechococcus. This probably explains why we now know much more about photosynthetic picoplanktonic prokaryotes than eukaryotes. In particular, the genetic diversity of these prokaryotes has been quite well characterized (Fuller et al., 2003; Rocap et al., 2002), representatives of key genotypes have been isolated in culture, and more recently quite a few genomes have been sequenced (Palenik et al., 2003; Rocap

Published by Copernicus Publications on behalf of the European Geosciences Union. 


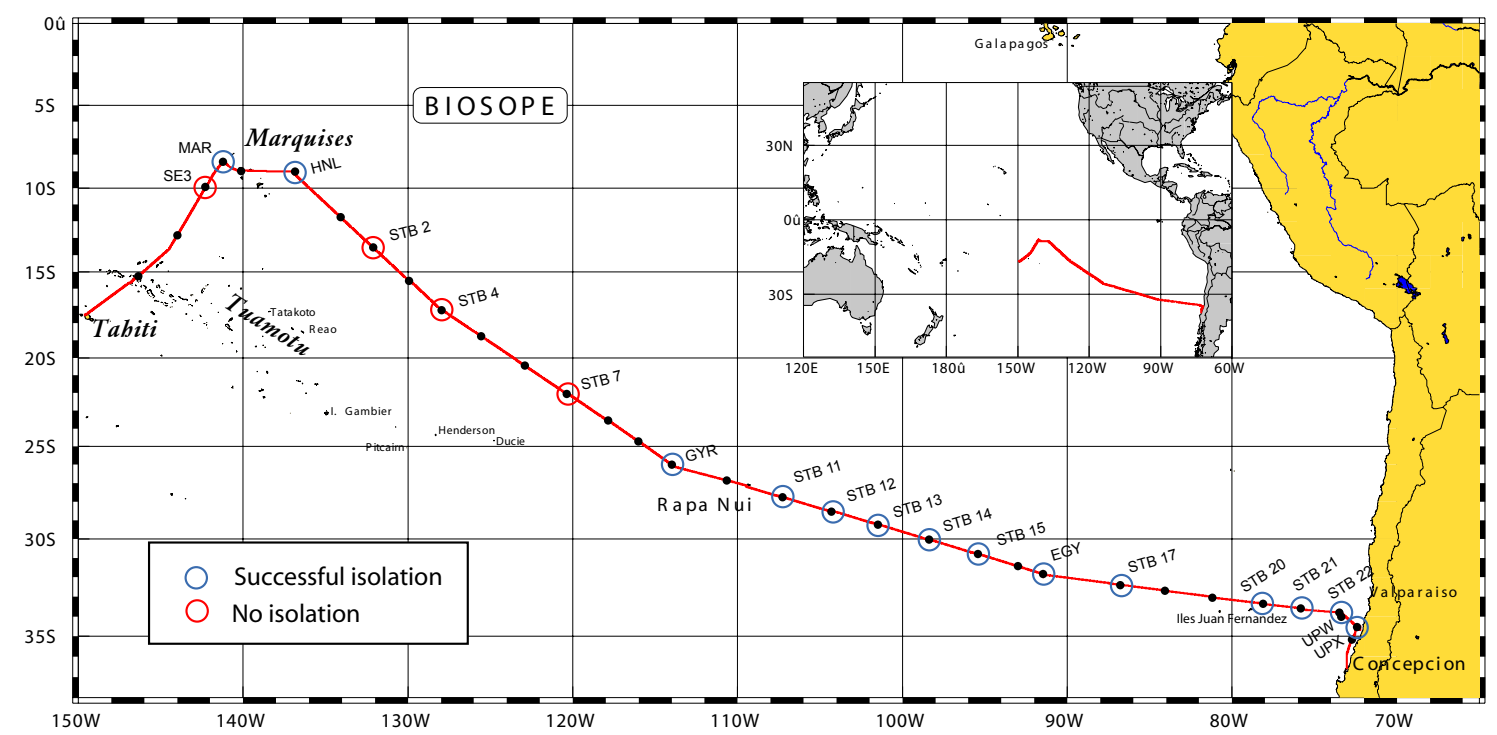

Fig. 1. BIOSOPE cruise track displaying the location of stations sampled for cultures.

et al., 2003). It is now possible to map the distribution of key groups of cyanobacteria in oceanic waters and to assess the existing relationships between genotypes and ecotypes (Johnson et al., 2006).

For photosynthetic picoeukaryotes, the situation is, in many respects, much less advanced, one reason being their very wide phylogenetic diversity. They belong to at least four major lineages: Chlorophyta, Haptophyta, stramenopiles (or Heterokontophyta) and Alveolata. Moreover, extensive studies of their genetic diversity from environmental samples started less than 10 years ago (López-García et al., 2001; Moon-van der Staay et al., 2001). To date, less than 25 species have been described for which cell size is always smaller than $3 \mu \mathrm{m}$ (Vaulot et al., 2008 ${ }^{1}$ ). Among these, knowledge about "flagship" species such as Ostreococcus and Micromonas (both belonging to the order Mamiellales, Prasinophyceae) is progressing fast since the genomes of several "ecotypes" have already been (or are currently) sequenced (Derelle et al., 2006; Palenik et al., 2007). Their oceanic distribution can be mapped using techniques such as fluorescent in situ hybridization (Not et al., 2005) or quantitative PCR (Marie et al., 2006). However, this only constitutes the tip of the iceberg as molecular approaches, in particular the analysis of $18 \mathrm{~S}$ rDNA genetic libraries from the natural environment, have pointed out to a very wide diversity at all taxonomic levels (Vaulot et al., 2008 ${ }^{1}$ ). For example, a new division of photosynthetic eukaryotes, the picobiliphytes, has been recently discovered (Not et al., 2007). Many phylogenetic groups are only known from their sequences. This is the case for example for Prasinophyceae clade VII B (Guillou

\footnotetext{
${ }^{1}$ Vaulot, D., Eikrem, W., Viprey, M., and Moreau, H.: The diversity of eukaryotic marine picophytoplankton, FEMS Microbiol. Rev., submitted, 2008.
}

et al., 2004) or for Chrysochromulina-related clades within the prymnesiophytes (Moon-van der Staay et al., 2000). For all these taxonomic groups, there is a critical need to obtain cultured representatives. This concern is especially acute in open ocean oligotrophic regions due to the difficulty to isolate and maintain organisms adapted to low nutrient conditions that are often outgrown by fast dividing "weed" species.

The BIOSOPE cruise that sailed through the center of the South East Pacific gyre, probably the most oligotrophic place on earth, offered an opportunity to obtain cultures from this unique environment. We performed sample enrichment with diluted culture medium following filtration to separate the smaller picoplankton cells from the rest of the plankton, a strategy that allowed us in the past to obtain novel taxa (Vaulot et al., 2004). We also targeted specifically photosynthetic picoeukaryotes by using flow cytometry sorting directly on board the ship. In the end, we obtained 212 cultures that have been integrated to the Roscoff Culture Collection (RCC, http://www.sb-roscoff.fr/Phyto/RCC/), more than half of which were characterized genetically by sequencing partially the 18S rRNA gene. These cultures encompass representatives of six major phylogenetic divisions: Cyanobacteria, Chlorophyta (mostly Prasinophyceae), stramenopiles, Haptophyta, Alveolata (dinoflagellates), Euglenozoa (bodonids). A significant fraction of these cultures are picoplanktonic, although for some groups such as the Alveolata, only large species were obtained. 
Table 1. Sampling stations and depths (in general two depths were selected corresponding to the two columns labelled min and max). The last three columns provide the number of starter cultures for each station obtained by either filtration on $0.6 \mu \mathrm{m}$, filtration on $3 \mu \mathrm{m}$, or by flow cytometry sorting.

\begin{tabular}{|c|c|c|c|c|c|}
\hline Station & $\begin{array}{l}\text { Depth min } \\
\quad(\mathrm{m})\end{array}$ & $\begin{array}{l}\text { Depth max } \\
\quad(\mathrm{m})\end{array}$ & $\begin{array}{l}\text { Cultures filtration } \\
\quad<0.6 \mu \mathrm{m}\end{array}$ & $\begin{array}{l}\text { Cultures filtration } \\
\quad<3 \mu \mathrm{m}\end{array}$ & $\begin{array}{l}\text { Cultures flow } \\
\text { cytometry sorting }\end{array}$ \\
\hline SE3 & 15 & 70 & & & 288 \\
\hline MAR & 10 & 60 & 10 & 20 & 288 \\
\hline HLN & 30 & 100 & 48 & 48 & 96 \\
\hline STB2 & 30 & 100 & & & 192 \\
\hline STB4 & 40 & 140 & & & 192 \\
\hline STB7 & 5 & 175 & & & 240 \\
\hline GYR2 & 5 & 500 & & 8 & 72 \\
\hline STB11 & 0 & 200 & & 12 & 48 \\
\hline STB12 & 40 & 180 & & & 48 \\
\hline STB13 & 0 & 160 & & 16 & \\
\hline STB14 & 5 & 150 & & & 72 \\
\hline STB15 & 100 & 100 & & & 48 \\
\hline EGY2 & 5 & 80 & 32 & & 112 \\
\hline STB17 & 0 & 20 & & & 19 \\
\hline STB20 & 5 & 45 & 16 & & 8 \\
\hline STB21 & 5 & 5 & & & 4 \\
\hline UPW1 & 5 & 35 & 16 & & 20 \\
\hline UPX & 0 & 40 & 16 & & 7 \\
\hline
\end{tabular}

\section{Material and methods}

\subsection{Sampling}

Samples were taken in general at two depths (surface layer and vicinity of the chlorophyll maximum when present) at selected stations along the BIOSOPE cruise track (Fig. 1 and Table 1) using Niskin bottles mounted on a CTD frame. The oceanographic context of the cruise is described in Claustre et al. (2008).

\subsection{Primary cultures}

We used two different strategies to obtain starter cultures. The first one was based on filtered seawater enriched with nutrients. The second one relied on single cell sorting by flow cytometry, targeting specific cell populations based on their size and pigment fluorescence. As cultures were examined several times during the cruise, many variations were attempted in an effort to increase final culture yield.

\subsubsection{Growth conditions used on board}

All cultures were incubated on board in a thermostatic cabinet set at $20^{\circ} \mathrm{C}$. Two light levels were obtained with 2 Sylvania $18 \mathrm{~W}$ tubes: white light around $140 \mu$ mol photons $\mathrm{m}^{-2} \mathrm{~s}^{-1}$ and blue light (Moon Light Blue paper, M.E.S, Nantes, France) around $8 \mu \mathrm{mol}$ photons $\mathrm{m}^{-2} \mathrm{~s}^{-1}$. We used three types of medium:
K (Keller et al., 1987) for photosynthetic eukaryotes, Pro2 (Moore and Chisholm, 1999) for photosynthetic prokaryotes (Prochlorococcus and Synechococcus), and rice-based (Cowling, 1991) for heterotrophic eukaryotes which were grown in the dark. Multi-well plates were wrapped with parafilm in order to avoid any evaporation during growth.

\subsubsection{Enrichment cultures}

About $500 \mathrm{~mL}$ of sample seawater was filtered by simple gravity through two superposed (in an effort to provide more tight size fractionation) Nuclepore filters of $47 \mathrm{~mm}$ diameter, with either $0.6 \mu \mathrm{m}$ or $3 \mu \mathrm{m}$ porosity (Whatman International Ltd, Maidstone, UK). The filtrate was partitioned into $50 \mathrm{~mL}$ culture flasks (Sarstedt, Orsay, France) or, at one station (HLN), into individual wells of 24-well plates to which we added either $1 / 10$ or $1 / 100$ of full strength $\mathrm{K}$ or Pro2 medium. In order to try to promote nitrogen fixing organisms, some cultures were started by simply amending sea water with iron $\left(\right.$ as $\left.\mathrm{FeCl}_{3}\right)$ and phosphorus $\left(\right.$ as $\left.\mathrm{KH}_{2} \mathrm{PO}_{4}\right)$ at final concentrations of $3 \mathrm{nM}$ and $0.4 \mu \mathrm{M}$, respectively.

\subsubsection{Cultures sorted by flow cytometry}

Samples were run either un-concentrated or concentrated between 5 and 100-fold by tangential flow filtration using a 100000 MWCO (Regenerated Cellulose - RC ref VF20C4) Vivaflow 200 cassette. Concentration was sometimes necessary so that rarer cells formed well defined populations in 
flow cytometry cytograms. Between 1 to 500000 cells were sorted using a FACSAria (Becton Dickinson, San Jose CA) flow cytometer either into 24 or 48 -well plates or directly into $10 \mathrm{~mL}$ polystyrene tubes pre-filled with medium diluted 100 times (Table S1, Supplement: http://www.biogeosciences. net/5/203/2008/bg-5-203-2008-supplement.pdf). Different cell populations were discriminated based on side scatter as well as orange and red fluorescence following excitation at $488 \mathrm{~nm}(20 \mathrm{~mW})$. Sorting was done either in purity or yield mode.

\subsection{Primary culture processing and establishment of strains}

On board the ship, primary cultures (either enriched or flow sorted) were checked for growth once or twice (depending on how early in the cruise they were started) using flow cytometry and inverted microscopy. Cultures that displayed growth but appeared mixed were sorted a second time.

A first set of cultures were transferred back to Roscoff on the occasion of change of crew at Easter Island at mid-cruise. At the end of the cruise, cultures from the early part of the cruise (i.e. about two months old) that showed no evidence of containing photosynthetic cells based on flow cytometry analysis were discarded. Cultures grown in multi-well plates were transferred to $10 \mathrm{~mL}$ polystyrene tubes. All cultures were brought back to Roscoff in the dark at ambient temperature in isothermal boxes to minimize temperature shocks. Cultures were exposed to moderate light when possible during the transit and then rushed to the Roscoff culture room on arrival.

Once transferred back to Roscoff, cultures were monitored based on colour as well as with optical microscopy and flow cytometry. Cultures were purified either by serial dilution, solid medium plating, or individual cell pipetting under an inverted microscope. Strains that appeared to be pure were transferred to normal strength medium: PCR-S11 (Rippka et al., 2000), K, and rice for cyanobacteria, autotrophic, and heterotrophic eukaryotes, respectively. They were then entered into the Roscoff Culture Collection (RCC) database under new accession numbers (Table S1, Supplement: http://www.biogeosciences.net/5/203/ 2008/bg-5-203-2008-supplement.pdf).

\subsection{Strain characterization}

Strains deposited to the RCC were characterized by optical microscopy. For each strain, pictures were taken on live cultures with an Olympus BX51 microscope with a $\times 100$ objective using differential interference contrast (DIC) with a SPOT RT-slider digital camera (Diagnostics Instruments, Sterling Heights, MI). Average cell dimension of each culture was determined from the pictures. Flagellated cells were also photographed after adding one drop of lugol to visualize flagellum shape, length and number. Cyanobacteria were identified by their colour and shape. The morphology of a few strains was confirmed by whole-mount transmission electron microscopy. Cells were fixed for $15 \mathrm{~min}$ with $1 \%$ glutaraldehyde (final concentration). A drop of fixed cells was deposited onto formvar-coated grids. Once the drop had dried, grids were rinsed with distilled water. Cells on grids were stained with a saturated solution of uranyl acetate for $20 \mathrm{~min}$ and rinsed with distilled water. Photomicrographs were taken with a JEOL JEM-1200EX electron microscope.

A subset of strains was characterized by their partial $18 \mathrm{~S}$ ribosomal RNA gene sequence. Cultures were grown in $50 \mathrm{~mL}$ flasks for 1-2 weeks depending on the growth of each strain and recovered by centrifugation at $11000 \times \mathrm{g}$ for 10 min. DNA was extracted using 3\% Cethyl Trimethyl Ammonium Bromide (CTAB, Doyle and Doyle, 1990). DNA was then stored at $-80^{\circ} \mathrm{C}$.

The 18S rRNA gene was amplified by polymerase chain reaction (PCR) using the primer set Euk328f and Euk329r (Romari and Vaulot, 2004) and the HotStarTaq Master Mix (Qiagen, Courtaboeuf, France). For PCR, a 15 min initial activation step of the polymerase at $95^{\circ} \mathrm{C}$, was followed by 40 cycles including $1 \mathrm{~min}$ of denaturation at $94^{\circ} \mathrm{C}, 45 \mathrm{~s}$ of annealing at $57^{\circ} \mathrm{C}$ and $75 \mathrm{~s}$ extension at $72^{\circ} \mathrm{C}$. The PCR program was finished by a final extension of $10 \mathrm{~min}$ at $72^{\circ} \mathrm{C}$ followed by cooling at $4^{\circ} \mathrm{C}$. PCR products were purified with the Qiaquick PCR purification kit (Qiagen) and controlled by electrophoresis on a $1 \%$ agarose gel. Partial $18 \mathrm{~S}$ rRNA gene sequences were determined from purified PCR products by using Big Dye Terminator V3.1 (Applied Biosystems, Foster city, CA, USA) and the internal primer Euk 528f (Elwood et al., 1985) run on an ABI prism 3100 sequencer (Applied Biosystems, Courtaboeuf, France).

Sequences were compared to those available in public database with NCBI BLAST web application. Sequences were also automatically aligned using the ARB program (Ludwig et al., 2004) to a set of more than 20000 high quality pre-aligned eukaryotic sequences (Pruesse et al., 2007) available from the Silva web site (SSURef database: www. arb-silva.de). After manual refinement of the alignment, sequences were added to the reference tree provided with the SSURef database using the quick parsimony addition option. Sequences with high similarities were grouped together using Fast Group II (http://biome.sdsu.edu/fastgroup/fg_tools. $\mathrm{htm}$ ) with the sequence match parameter set at $80 \%$ and one or two representative sequences per group were chosen along with the closest publicly available sequence. Phylogeny analysis was performed on aligned sequences with MEGA4 (http://www.megasoftware.net/, Tamura et al., 2007). A neighbour-joining tree was computed from 394 common positions based on Kimura 2-parameter model distances using 1000 bootstrap replications. Sequences have been submitted to GenBank under accession number EU106736-EU106852. 


\section{Results and discussion}

\subsection{Isolation success}

All together more than 1900 starter cultures were established during the BIOSOPE cruise (Table 1) either as enrichment cultures following filtration through either 0.6 or $3 \mu \mathrm{m}$ or by sorting specific populations into individual wells or tubes. From one to three purification steps were in general necessary to obtain pure cultures (Table S1, Supplement: http://www.biogeosciences.net/5/203/ 2008/bg-5-203-2008-supplement.pdf). For example, enrichment cultures started at the beginning of the cruise were sorted at the end of the cruise and then purified by serial dilution back in the laboratory.

In the end, we obtained 188 autotrophic and 24 heterotrophic cultures which have been deposited to the RCC (Table S2, Supplement: http://www.biogeosciences.net/5/ 203/2008/bg-5-203-2008-supplement.pdf). Among these, 13 were subsequently lost and 25 remain not pure to this date. The latter are mostly autotrophic strains contaminated by heterotrophic eukaryotes. Cruise coverage was quite unequal with many strains obtained in mesotrophic regions and in the Chilean upwelling and much fewer from the central gyre (Fig. 1 and Table S1, Supplement: http://www.biogeosciences.net/5/203/ 2008/bg-5-203-2008-supplement.pdf). This reflects probably the difficulty to obtain cultures representative of extreme oligotrophic conditions, since nutrient additions even at relatively low concentrations are always much higher than those found in the environment. However this unbalanced coverage is not only the consequence of the environment but also of practical considerations. Cultures started early during the cruise had a chance to be screened before the end of the cruise and therefore could be re-purified on-board the ship. Conversely, cultures started late in the cruise were transported during their initial acclimation phase. Refinements in culturing conditions that were implemented late in the cruise based upon results obtained in the first part of the cruise may also explain why our success rate was better by the end of the cruise. For example, at the beginning of the cruise, starter cultures were sorted into 24 or 48 -well plates. By mid-cruise, as we did not observe any growth under these conditions, we decided to switch to sorting into $10-\mathrm{mL}$ tubes which seemed to result in higher success rates.

Sorting was an important element since more than $65 \%$ of the final cultures had undergone at least one sorting step. The strategy that yielded most pure strains was first to establish an enrichment culture with either 0.6 or $3 \mu \mathrm{m}$ filtered samples followed by sorting sometimes later. In this case, it was often not necessary to perform further purification by serial dilution, saving this labour-intensive step. Sorting directly from natural samples was rarely sufficient to produce pure cultures and in most cases a second purification step had to be undertaken. It is difficult to determine whether sorting was

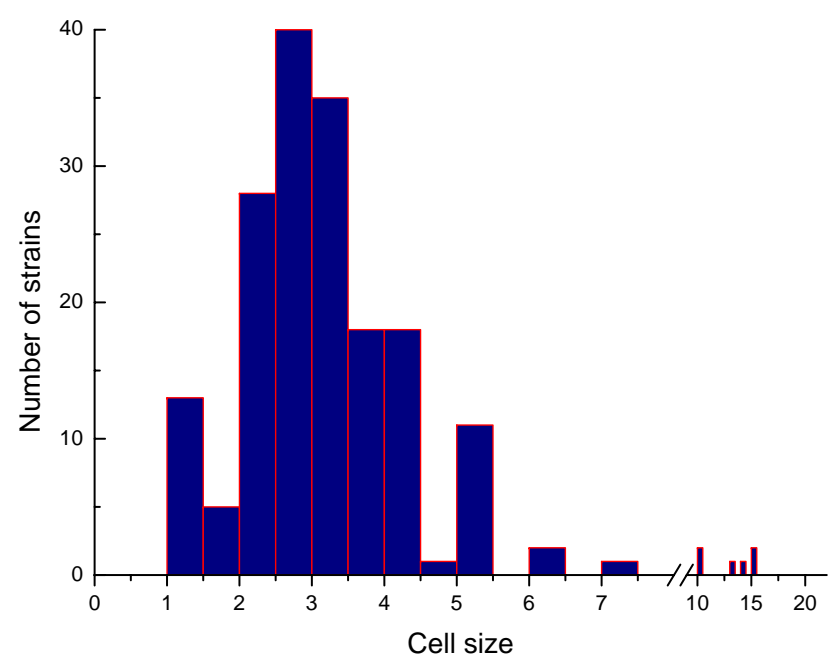

Fig. 2. Histogram of average sizes for all RCC cultures recovered from the BIOSOPE cruise.

successful in isolating the initially targeted population. We sorted sub-populations on the base of side scatter and chlorophyll but each of these sub-populations does not appear to be uniform genetically and consists probably of a mixture of several taxa belonging to different algal classes as established by $18 \mathrm{~S}$ cloning and sequencing of sorted cells (X. Shi and D. Marie, unpublished).

\subsection{Culture diversity}

All purified cultures were examined by light microscopy, imaged digitally and their average size was determined (Fig. 2 and Tables S1 and S2, Supplement: http://www.biogeosciences.net/5/203/2008/ bg-5-203-2008-supplement.pdf). No attempts were made to record measurements for a large number of cells in each culture and size data are therefore only indicative. They confirm, however, that our efforts to target picoplankton were successful since the mode size for the culture set lies between 2.5 and $3 \mu \mathrm{m}$.

A large, randomly chosen, subset of cultures (115, Tables S1 and S2, Supplement: http://www.biogeosciences. net/5/203/2008/bg-5-203-2008-supplement.pdf) was analysed phylogenetically by sequencing either partially or, in a few cases, totally the $18 \mathrm{~S}$ rRNA gene. A few other cultures were identified based on their phenotypic characteristics (cyanobacteria, microplanktonic species).

Representatives of cyanobacteria and of three major eukaryotic divisions containing photosynthetic organisms (stramenopiles, Chlorophyta, and Haptophyta) have been obtained in culture with the former most prevalent and the latter two in almost equal proportions (Table 2). For these groups, a large fraction of the strains were picoplanktonic. This contrasts with the Alveolata for which only two larger sized $(15 \mu \mathrm{m})$ dinoflagellate cultures could be isolated 
Table 2. Number of strains identified for the different phylogenetic groups.

\begin{tabular}{|c|c|c|c|c|}
\hline Division & Class & Genus & Number & Total per division \\
\hline Cyanobacteria & Cyanophyceae & Synechococcus & 13 & 13 \\
\hline \multirow[t]{7}{*}{ Chlorophyta } & Prasinophyceae & Micromonas & 2 & 30 \\
\hline & Prasinophyceae & Prasinococcus & 1 & \\
\hline & Prasinophyceae & Prasinoderma & 2 & \\
\hline & Prasinophyceae & cf. Prasinoderma & 9 & \\
\hline & Prasinophyceae & Pycnococcus & 5 & \\
\hline & Prasinophyceae & Unknown & 8 & \\
\hline & Trebouxiophyceae & Picochlorum & 3 & \\
\hline \multirow[t]{11}{*}{ Stramenopiles } & Bacillariophyceae & Chaetoceros & 1 & 58 \\
\hline & Bacillariophyceae & Minutocellus & 1 & \\
\hline & Bacillariophyceae & Thalassiosira & 1 & \\
\hline & Bolidophyceae & Bolidomonas & 1 & \\
\hline & Dictyochophyceae & Florenciella & 2 & \\
\hline & Pelagophyceae & Pelagomonas & 38 & \\
\hline & Pelagophyceae & Unknown & 2 & \\
\hline & Unknown & Unknown & 2 & \\
\hline & Bicosoecid & Caecitellus & 4 & \\
\hline & Bicosoecid & Cafeteria & 3 & \\
\hline & Bicosoecid & Unknown & 3 & \\
\hline \multirow[t]{3}{*}{ Haptophyta } & Prymnesiophyceae & Emiliania & 12 & 28 \\
\hline & Prymnesiophyceae & Phaeocystis & 14 & \\
\hline & Prymnesiophyceae & Unknown & 2 & \\
\hline Alveolata & Dinophyceae & Prorocentrum & 2 & 2 \\
\hline Kinetoplastida & Bodonid & Unknown & 2 & 2 \\
\hline
\end{tabular}

(see Tables S2, Supplement: http://www.biogeosciences.net/ 5/203/2008/bg-5-203-2008-supplement.pdf).

Thirteen strains of unicellular rod-shaped cyanobacteria have been obtained tentatively identified as Synechococcus. No Prochlorococcus was obtained despite the use of the Prochlorococcus specific Pro2 medium. Some of these cyanobacterial strains form short chains, exhibiting sometimes very elongated cells (Fig. 3, RCC 1027) contrasting the usual Synechococcus morphology (Fig. 3, RCC 1022). Such strains mostly originated from the HNLC station near the Marquesas Islands (see Supplement: http://www.biogeosciences.net/5/ 203/2008/bg-5-203-2008-supplement.pdf, Table S1). Interestingly, samples from this region displayed an unusually high fraction of chain-forming and colonial picocyanobacteria (Masquelier and Vaulot, 2007). Phylogenetic analyses of the $16 \mathrm{~S}$ rRNA gene will be necessary to determine the exact nature of these strains.

Chlorophyta, and more specifically Prasinophyceae, are important contributors to picoplankton and many strains have been isolated from marine waters in the past, some of them belonging to yet undescribed species (Guillou et al., 2004; Vaulot et al., 2004). Thirty Chlorophyta strains have been isolated during BIOSOPE, mostly Prasinophyceae. Among these, 11 are related to Prasinoderma coloniale (Prasinococ- cales), a picoplanktonic species that can form colonies surrounded by mucus. These strains display the bilobed cupshaped chloroplasts characteristics of $P$. coloniale (Hasegawa et al., 1996). However most of our strains do not seem to form colonies as $P$. coloniale does. Interestingly, one group of 9 sequences appears to form a separate clade (Fig. 4) with only $94.7 \%$ identity to $P$. coloniale, in contrast to the two other strains sharing $99.6 \%$ identity with $P$. coloniale. These sequences possess large and highly similar insertions at least $330 \mathrm{bp}$ long inside the 18S rRNA gene starting at nucleotide position 862 of the $P$. coloniale sequence. Phenotypically, strains from these group appear slightly smaller (see Table S2, Supplement: http://www.biogeosciences.net/5/203/ 2008/bg-5-203-2008-supplement.pdf) than those closely related to $P$. coloniale. They were isolated from near-surface waters at a variety of stations, while the two strains more closely related to $P$. coloniale originated from the Marquesas area. A culture closely related to Prasinococcus capsulatus, a species that also belongs to the order Prasinococcales, has been recovered from the chlorophyll maximum at the GYR station. Cells display a polysaccharide capsule around the cell (Fig. 3, RCC 859), typical of this species (Miyashita et al., 1993). Five Prasinophyceae closely related to the picoplanktonic species Pycnococcus provasolii (Pseudoscourfieldiales) have been isolated from two mid-depth 
samples in the Chilean upwelling. Eight strains belong to clade VII of the Prasinophyceae (Guillou et al., 2004), a group which contains some cultured strains such as CCMP 1205 but for which no species has been described formally. All these strains consist of small ( 2 to $4 \mu \mathrm{m}$ ) spherical cells lacking discriminating features (Fig. 3, RCC 857). Two sets of strains originated from surface waters and one set from $100 \mathrm{~m}$ in the HNLC zone. Two Prasinophyceae strains from the Chilean upwelling belong to clade $\mathrm{C}$ of the very ubiquitous species Micromonas pusilla (Guillou et al., 2004). They possess an unusually long flagellum (Fig. 3, RCC 913) that could be a diagnostic feature for that clade (F. Jouenne, personal communication). We also isolated from one sample of the Chilean upwelling three cultures representative of another green algal class, the Trebouxiophyceae. These strains are phylogenetically related to the recently established genus Picochlorum (Fig. 4) that now regroups salt-tolerant species previously classified within the genus Nanochlorum (Henley et al., 2004).

All Haptophyta cultures are part of the class Prymnesiophyceae. Fourteen strains belong to the genus Phaeocystis. Among these, three from the upwelling region (RCC 908, 925 and 935 ) are closely related ( $>99.5 \%$ sequence similarity) to $P$. jahnii. This species has been recently described from the Mediterranean Sea (Zingone et al., 1999) and forms loose colonies. Nine strains from the Marquesas, east of the gyre and upwelling regions (RCC 851, 870, 882, 940, $992,993,1000,1006,1003)$ are closely related $(>99.5 \%$ sequence similarity) to $P$. globosa that forms spherical colonies (Fig. 3, RCC 851). Another Phaeocystis strain (RCC 861) is more distantly (98\%) related to P. globosa. For the last strain (RCC 849), no sequence is available. We also isolated 12 strains of Emiliania huxleyi, a few calcifying (Fig. 3, RCC 867) and most naked (Fig. 3, RCC 951), corresponding probably to diploid and haploid stages, respectively (Houdan et al., 2003). Two other unidentified coccolithophorids have also been obtained from the Marquesas and central gyre regions. Interestingly all Haptophyta strains were isolated from the top of euphotic zone (between 5 and $60 \mathrm{~m}$ ).

Among stramenopiles, 38 cultures are closely related to the picoplanktonic species Pelagomonas calceolata (Pelagophyceae). The 37 available sequences share more than $99 \%$ similarity over 335 common positions and 34 are even 100\% identical to each other. More than half of the strains are flagellated (Fig. 3, RCC 879), fitting the original description of the species (Andersen et al., 1993), while the other do not display any evidence of a flagellum. However, the presence of a flagellum could reflect life cycle stages rather than taxonomical differences. Interestingly, both flagellated and non-flagellated strains with identical $18 \mathrm{~S}$ rDNA sequences have been isolated from the same sample: e.g. RCC 883 and 884 originated from $100 \mathrm{~m}$ at the HLN station and share $100 \%$ sequence similarity over 697 positions. The presence of a thin theca characteristics of the species (Andersen et al., 1993) was confirmed by electron microscopy on strain

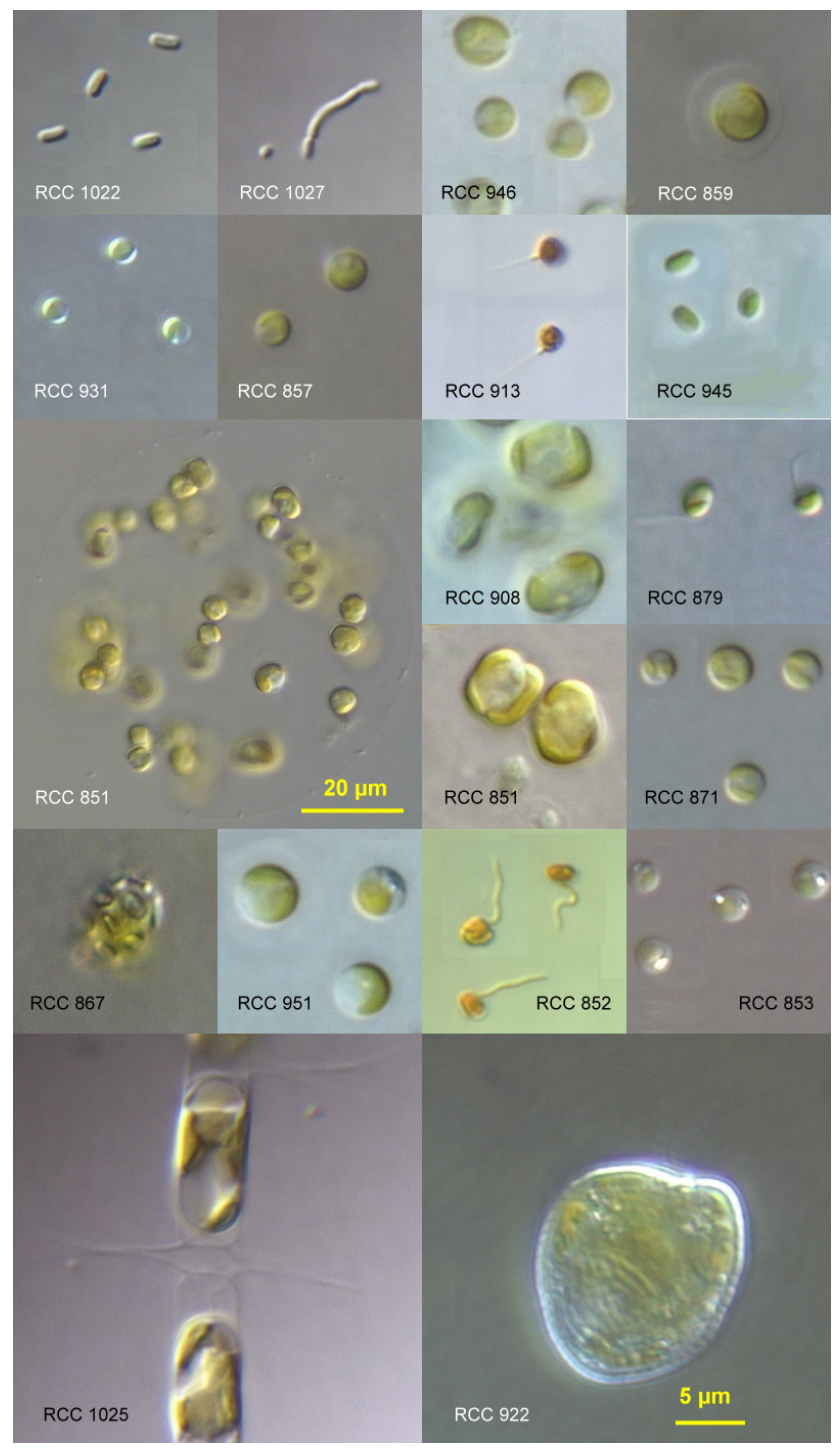

Fig. 3. Microscopy images of a selection of strains recovered during the BIOSOPE cruise. Scale bar is $5 \mu \mathrm{m}$ for all images except for the Phaeocystis colony (RCC 851). From top to bottom and from left to right. Cyanobacteria: RCC 1022 and 1027. Note the elongated shape and short chains made by RCC 1027. Prasinophyceae: Prasinoderma sp. (RCC 946), Prasinococcus capsulatus (RCC 859), Pycnococcus provasolii (RCC 931), undescribed species belonging to clade VII (RCC 857), and Micromonas pusilla (RCC 913). Trebouxiophyceae: Picochlorum sp. (RCC 945). Prymnesiophyceae: Phaeocystis sp. (RCC 851 and 908, note colonial form) and Emiliana huxleyi (RCC 867, calcifying, and RCC 951, not calcifying). Pelagophyceae: Pelagomonas calceolata (RCC 879, flagellated lugol fixed, and RCC 871, spherical). Bolidophyceae: Bolidomonas sp. (RCC 852, lugol fixed). Heterokontophyta: unknown species (RCC 853). Diatom: Chaetoceros sp. (RCC 1025). Dinoflagellate: Prorocentrum minimum (RCC 922). 


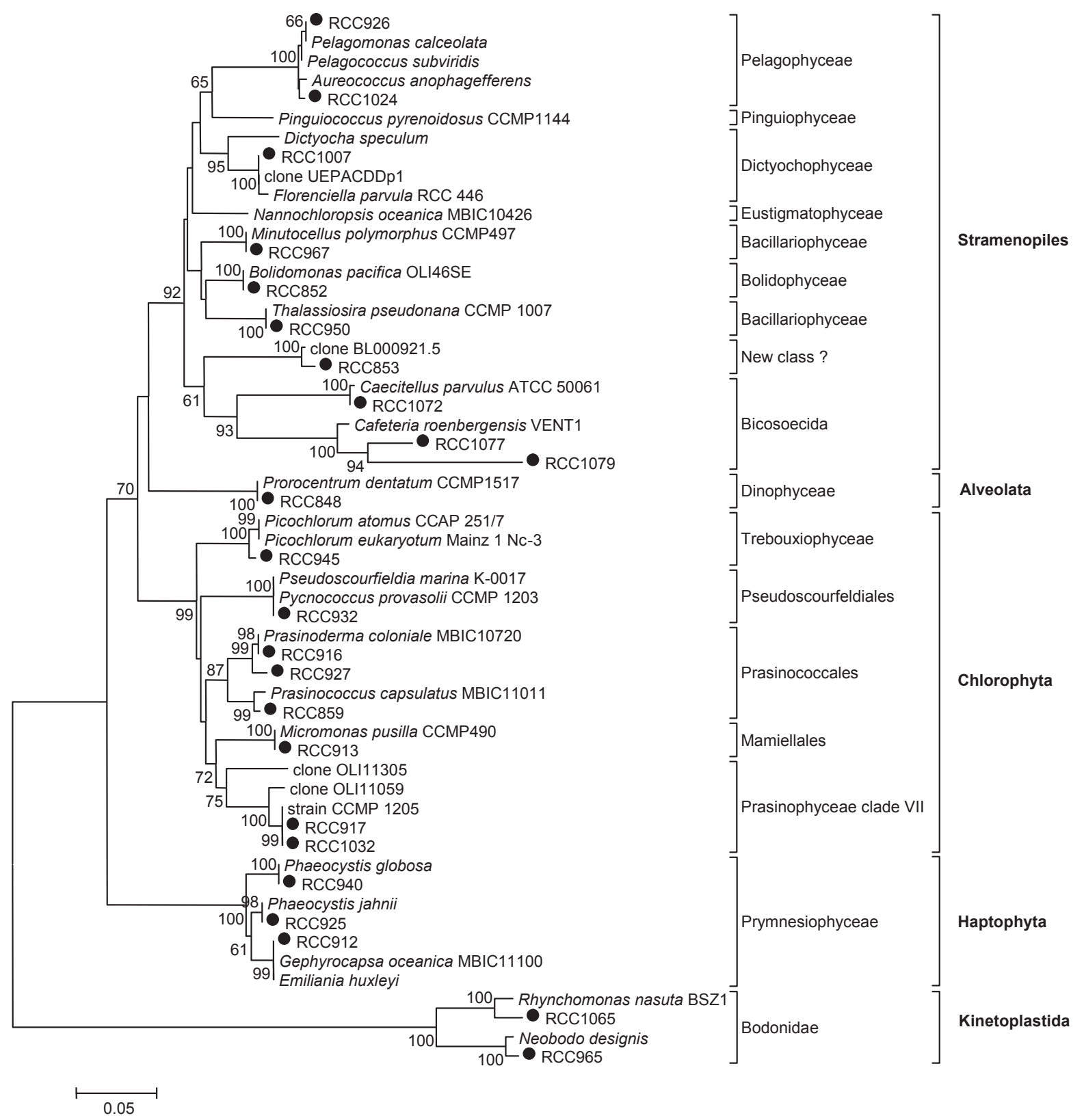

Fig. 4. Phylogenetic analysis of selected strains recovered during the BIOSOPE cruise. One or two 18S rDNA sequences from each taxonomic group was selected following clustering with Fast Group II (see Material and Methods). Neighbour-joining optimal tree with the sum of branch length $=1.74$ shown. The percentage of replicate trees in which the associated taxa clustered together in the bootstrap test (1000 replicates) is displayed next to the branches. Only values larger than $60 \%$ are shown. The tree is drawn to scale, with branch lengths in the same units as those of the evolutionary distances used to infer the phylogenetic tree. The evolutionary distances were computed using the Kimura 2-parameter method and are in the units of the number of base substitutions per site. All positions containing gaps and missing data were eliminated from the dataset (complete deletion option). There were a total of 394 positions in the final dataset. Phylogenetic analyses were conducted with MEGA4 (http://www.megasoftware.net/).

RCC 879. P. calceolata was isolated at a variety of stations (Marquesas, HLNC, center of gyre, east of gyre and upwelling) both in surface and at $100 \mathrm{~m}$, demonstrating that this species is truly ubiquitous in oceanic waters. Interestingly in the center of the South East gyre, Pelagomonas strains were isolated from very deep samples down to $160 \mathrm{~m}$. Two Pelagophyceae strains (RCC 986 and 1024) with 18S rDNA sequences displaying slightly lower similarity to $P$. calceolata (Fig. 4) were recovered at $60 \mathrm{~m}$ depth from the Marquesas region. Both are picoplanktonic and spherical, not 
displaying any specific morphological features. We isolated a novel strain with high similarity to Bolidomonas pacifica, a species that belongs to the recently described class of the Bolidophyceae (Guillou et al., 1999), closely related to the diatoms. Its morphology (presence of 2 heterokont flagella) was confirmed by electron microscopy. This is quite interesting since to our knowledge this is the first novel isolate from this class since its initial discovery. In the same manner, we isolated from Marquesas surface waters, two strains very closely related by their $18 \mathrm{~S}$ rDNA sequence to the recently described Dictyochophyceae picoplanktonic species Florenciella parvula (Eikrem et al., 2004). Similarity was also confirmed by electron microscopy. Two photosynthetic stramenopile strains could not be assigned to any specific class. Their $18 \mathrm{~S}$ sequences share some homology with both Pinguiococcus (Pinguiophyceae) and Nannochloropsis (Eustigmatophyceae) and are almost identical to an environmental 18S sequence (BL000921.5) recovered from Blanes Bay in the Mediterranean Sea (Fig. 4). They could belong to a new class, although the presence of refractive intracellular granules (Fig. 3, RCC 853) is quite reminiscent of what is observed in Nannochloropsis. Unfortunately, these strains have been lost in early 2007 following a breakdown in the air conditioning system of our culture facility. Their loss, which was almost the only one from a quite large collection, attests of their sensitivity to change in environmental conditions and may explain why representatives of this group have not been isolated before.

Three diatoms, belonging to the genera Chaetoceros (Fig. 3, RCC 1025), Thalassiosira and Minutocellus were obtained from the upwelling region. The latter strain is quite interesting since its very small size (about $3 \mu \mathrm{m}$ ) connects it to picoplankton. Two dinoflagellates belonging to the genus Prorocentrum, P. minimum (Fig. 3, RCC 922) and P. dentatum, were isolated from surface waters, east of the gyre.

Twelve heterotrophic strains from dark cultures growing on rice medium have been identified by their $18 \mathrm{~S}$ rDNA sequences. Ten belong to the bicosoecid lineage of the stramenopiles. Three cultures are quite closely related to the genus Caecitellus and four more distantly related to Cafeteria. The two remaining strains were closely related to the bodonid (Euglenozoa) genera Rhynchomonas and Neobodo. All these heterotrophic genera are quite often recovered in cultures (Arndt et al., 2003).

\section{Conclusions}

Our large scale effort to isolate picoplanktonic strains from the Southeast Pacific Ocean allowed us to obtain of 212 novel cultures, a large number of which are of picoplanktonic size. The final number of cultures obtained is substantially higher than in previous efforts such as those linked to the PROSOPE and MINOS cruises in the Mediterranean Sea or the OLIPAC cruise in the Equatorial Pacific Ocean for which we obtained between 46 and 90 strains for each (Vaulot et al., 2004). Our initial intent was to use mostly flow cytometry sorting to establish strains. However as we experienced technical problems with flow cytometry in the first few days of the cruise and as we observed subsequently that the yield of the initially sorted samples was quite low, we decided to combine flow cytometry sorting with more classical enrichments. This proved to be quite a good recipe. In particular sorting based on photosynthetic pigment fluorescence appears to be a good way to prevent contamination of cultures by heterotrophic eukaryotes, a problem plaguing some of our previous efforts. The application of sorting either before or after enrichment did not appear to affect dramatically the type of taxa isolated (see Table S1, Supplement: http://www.biogeosciences.net/ 5/203/2008/bg-5-203-2008-supplement.pdf).

The final diversity achieved is quite wide since we obtained representatives of most major photosynthetic divisions (Table 2). However it is clear that we globally failed to obtain representatives of environmental sequences for which no culture is available yet. One interesting group of novel cultures was constituted by stramenopile strains RCC 853 and 862 from the central gyre which sequences were closely related to an environmental sequence from the Mediterranean Sea (Fig. 4). Although these sequences had some affinities, based on BLAST, to Eustigmatophyceae and their morphology was somewhat similar to the latter, they probably belonged to a novel class. Despite the fact that further studies are prevented since these strains have been lost, the strategy used (flow cytometry sorting followed by serial dilution) could be tried again to re-isolate them. Another interesting group is constituted by 9 cultures originating from the region east of the gyre and from the upwelling that are related to Prasinoderma but form a new clade clearly separated from the species $P$. coloniale (Fig. 4). They could belong to a new species within the genus Prasinoderma or form a new genus. Interestingly, they are apparently not related to any published environmental sequence. All the other cultures obtained are related to described species or at least to established cultures. In particular, we have been successful at re-isolating two genera Bolidomonas and Florenciella that our group had previously isolated and described (Eikrem et al., 2004; Guillou et al., 1999), but that had never been obtained again in culture since their initial isolation. Interestingly, B. pacifica was initially isolated from exactly the same region (between 2 and $16^{\circ} \mathrm{S}$ ) as the new strain ( $\left.9^{\circ} \mathrm{S}\right)$. In contrast, the only $F$. parvula strain available previously originated from English Channel coastal waters, a very different environment from that of the new strains. Moreover the $18 \mathrm{~S}$ sequences of the latter differ slightly from that of $F$. parvula and they could belong to a novel species within this genus. Some of the cultures recovered correspond to ubiquitous species that were obtained from a wide range of environments. This is in particular the case for the two Haptophyta genera Emiliania, isolated from two of the four major regions investigated (Marquesas, east of gyre) and Phaeocystis isolated from three regions 
(Marquesas, east of the gyre, Chilean upwelling) mostly in surface waters. For the latter genus, our strains may correspond to at least two different species, $P$. globosa and $P$. jahnii. However, the largest number of strains obtained for a single taxon correspond to Pelagomonas isolated from a record of 13 different samples along the entire cruise track ranging from oligotrophic (St B13) to eutrophic (UPX) and from surface $(5 \mathrm{~m})$ to very deep $(160 \mathrm{~m})$ samples. Although the similarity of their 18S rRNA gene sequence is very high, it is likely that these strains present quite different growth responses to factors such as nitrogen supply or light levels and belong to different ecotypes, as observed previously for example for the genus Ostreococcus (Rodríguez et al., 2005).

From a biogeographic point of view, it is quite difficult to make any firm conclusion from this work. Many cultures belonging to a given taxonomic group were isolated from a variety of conditions and no specific pattern could be uncovered. Although there were some taxa unique to the central part of the gyre itself (Stations 3 to 15) such as Prasinococcus and the potentially novel class mentioned earlier, one should emphasize the low number of strains isolated from this region. This is probably linked to the fact that the media we used (K, Pro2), that are quite successful in general to isolate and maintain a wide variety of picophytoplankton strains, fail to mimic the drastic oligotrophic conditions met in the gyre. Moreover future isolation effort may need to involve new culture approaches (Zengler et al., 2002) such as those successful to isolate fastidiously growing bacterial strains from the open ocean environment such as Pelagibacter ubique (aka SAR11) that had escaped cultivation for quite a long time (Rappé et al., 2002).

Acknowledgements. We wish to thank the crew of the NO Atalante for their critical help in repairing the FACSAria flow cytometer during the cruise as well as for their constant availability. We are grateful to all participants to the BIOSOPE cruise, especially to H. Claustre and A. Sciandra, who coordinated the cruise and acted as chief scientists. Help for microscopy from F. Jouenne is kindly acknowledged. L. Guillou provided very helpful comments on several versions of the paper. Financial support for this work was provided by the following programs and companies: ANR Biodiversité (project PICOFUNPAC), CNRS INSU PROOF, Contrat de Plan Etat Région (Souchothèque de Bretagne), Becton Dickinson.

Edited by: A. Boetius

\section{References}

Andersen, R. A., Saunders, G. W., Paskind, M. P., and Sexton, J.: Ultrastructure and 18S rRNA gene sequence for Pelagomonas calceolata gen. and sp. nov. and the description of a new algal class, the Pelagophyceae classis nov., J. Phycol., 29, 701-715, 1993.

Arndt, H., Hausmann, K., and Wolf, M.: Deep-sea heterotrophic nanoflagellates of the Eastern Mediterranean Sea: qualitative and quantitative aspects of their pelagic and benthic occurrence, Mar. Ecol. Prog. Ser., 256, 45-56, 2003.

Claustre, H., Sciandra, A., and Vaulot, D.: Introduction to the special section: bio-optical and biogeochemical conditions in the South East Pacific in late 2004 - the BIOSOPE program, Biogeosciences Discuss., 5, 605-640, 2008, http://www.biogeosciences-discuss.net/5/605/2008/.

Cowling, A. J.: Free-living heterotrophic flagellates: methods of isolation and maintenance, including sources of strains in culture, in: The Biology of Free-Living Heterotrophic Flagellates, edited by: Patterson, D. J. and Larsen, J., Clarendon Press, 477-492, 1991.

Derelle, E., Ferraz, C., Rombauts, S., Rouze, P., Worden, A. Z., Robbens, S., Partensky, F., Degroeve, S., Echeynie, S., Cooke, R., Saeys, Y., Wuyts, J., Jabbari, K., Bowler, C., Panaud, O., Piegu, B., Ball, S. G., Ral, J.-P., Bouget, F.-Y., Piganeau, G., De Baets, B., Picard, A., Delseny, M., Demaille, J., Van de Peer, Y., and Moreau, H.: Genome analysis of the smallest free-living eukaryote Ostreococcus tauri unveils many unique features, Proc. Natl. Acad. Sci. USA, 103, 11 647-11 652, 2006.

Doyle, J. J. and Doyle, J. L.: Isolation of plant DNA from fresh tissue, Focus, 12, 13-15, 1990.

Eikrem, W., Romari, K., Latasa, M., Le Gall, F., Throndsen, J., and Vaulot, D.: Florenciella parvula gen. and sp. nov. (Dictyochophyceae, Heterokontophyta) a small flagellate isolated from the English Channel, Phycologia, 43, 658-668, 2004.

Elwood, H. J., Olsen, G. J., and Sogin, M. L.: The small-subunit ribosomal RNA gene sequences from the hypotrichous ciliates Oxytricha nova and Stylonychia pustulata, Mol. Biol. Evol., 2, 399-410, 1985.

Fuller, N. J., Marie, D., Partensky, F., Vaulot, D., Post, A. F., and Scanlan, D. J.: Clade-specific 16S ribosomal DNA oligonucleotides reveal the predominance of a single marine Synechococcus clade throughout a stratified water column in the Red Sea, Appl. Environ. Microbiol., 69, 2430-2443, 2003.

Guillou, L., Chrétiennot-Dinet, M.-J., Medlin, L. K., Claustre, H., Loiseaux-de Goër, S., and Vaulot, D.: Bolidomonas: a new genus with two species belonging to a new algal class, the Bolidophyceae (Heterokonta), J. Phycol., 35, 368-381, 1999.

Guillou, L., Eikrem, W., Chrétiennot-Dinet, M. J., Le Gall, F., Massana, R., Romari, K., Pedrós-Alió, C., and Vaulot, D.: Diversity of picoplanktonic prasinophytes assessed by direct nuclear SSU rDNA sequencing of environmental samples and novel isolates retrieved from oceanic and coastal marine ecosystems, Protist, 155, 193-214, 2004.

Hasegawa, T., Miyashita, H., Kawachi, M., Ikemoto, H., Kurano, N., Miyachi, S., and Chihara, M.: Prasinoderma coloniale gen. nov. et sp. nov., a new pelagic coccoid prasinophyte from the western Pacific Ocean, Phycologia, 35, 170-176, 1996.

Henley, W. J., Hironaka, J. L., Guillou, L., Buchheim, M. A., Buchheim, J. A., Fawley, M. W., and Fawley, K. P.: Phylogenetic analysis of the 'Nannochloris-like' algae and diagnoses of Picochlorum oklahomensis gen. et sp nov (Trebouxiophyceae, Chlorophyta), Phycologia, 43, 641-652, 2004.

Herbland, A., Le Bouteiller, A., and Raimbault, P.: Size structure of phytoplankton biomass in the equatorial Atlantic Ocean, DeepSea Res. I, 32, 819-836, 1985.

Houdan, A., Billard, C., Marie, D., Not, F., Saez, A. G., Young, J. R., and Probert, I.: Holococcolithophore-heterococcolithphore 
(Haptophyta) life cycles: flow cytometric analysis of relative ploidy levels, Syst. Biodivers., 4, 453-465, 2003.

Johnson, P. W. and Sieburth, J. M.: In-situ morphology and occurence of eucaryotic phototrophs of bacterial size in the picoplankton of estuarine and oceanic waters, J. Phycol., 18, 318327, 1982.

Johnson, Z. I., Zinser, E. R., Coe, A., McNulty, N. P., Woodward, E. M. S., and Chisholm, S. W.: Niche partitioning among Prochlorococcus ecotypes along ocean-scale environmental gradients, Science, 311, 1737-1740, 2006.

Keller, M. D., Selvin, R. C., Claus, W., and Guillard, R. R. L.: Media for the culture of oceanic ultraphytoplankton, J. Phycol., 23, 633-638, 1987.

Li, W. K. W., Subba Rao, D. V., Harrison, W. G., Smith, J. C., Cullen, J. J., Irwin, B., and Platt, T.: Autotrophic picoplankton in the tropical ocean, Science, 219, 292-295, 1983.

López-García, P., Rodriguez-Valera, F., Pedrós-Alió, C., and Moreira, D.: Unexpected diversity of small eukaryotes in deep-sea Antarctic plankton. Nature, 409, 603-607, 2001.

Ludwig, W., Strunk, O., Westram, R., Richter, L., Meier, H., Yadhukumar, Buchner, A., Lai, T., Steppi, S., Jobb, G., Forster, W., Brettske, I., Gerber, S., Ginhart, A. W., Gross, O., Grumann, S., Hermann, S., Jost, R., Konig, A., Liss, T., Lussmann, R., May, M., Nonhoff, B., Reichel, B., Strehlow, R., Stamatakis, A., Stuckmann, N., Vilbig, A., Lenke, M., Ludwig, T., Bode, A., and Schleifer, K. H.: ARB: a software environment for sequence data, Nucleic Acids Res., 32, 1363-1371, 2004.

Marie, D., Zhu, F., Balagué, V., Ras, J., and Vaulot, D.: Eukaryotic picoplankton communities of the Mediterranean Sea in summer assessed by molecular approaches (DGGE, TTGE, QPCR), FEMS Microbiol. Ecol., 55, 403-415, 2006.

Masquelier, S. and Vaulot, D.: Distribution of micro-organisms along a transect in the South-East Pacific Ocean (BIOSOPE cruise) from epifluorescence microscopy, Biogeosciences Discuss., 4, 2667-2697, 2007,

http://www.biogeosciences-discuss.net/4/2667/2007/.

Miyashita, H., Ikemoto, H., Kurano, N., Miyachi, S., and Chihara, M.: Prasinococcus capsulatus gen. et sp. nov., a new marine coccoid prasinophyte, J. Gen. Appl. Microbiol., 39, 571-582, 1993.

Moon-van der Staay, S. Y., De Wachter, R., and Vaulot, D.: Oceanic $18 \mathrm{~S}$ rDNA sequences from picoplankton reveal unsuspected eukaryotic diversity, Nature, 409, 607-610, 2001.

Moon-van der Staay, S. Y., van der Staay, G. W. M., Guillou, L., Vaulot, D., Claustre, H., and Medlin, L. K.: Abundance and diversity of prymnesiophytes in the picoplankton community from the equatorial Pacific Ocean inferred from 18S rDNA sequences, Limnol. Oceanogr., 45, 98-109, 2000.

Moore, L. R. and Chisholm, S. W.: Photophysiology of the marine cyanobacterium Prochlorococcus: Ecotypic differences among cultured isolates, Limnol. Oceanogr., 44, 628-638, 1999.

Nägeli, C.: Gattungen einzelliger Algen physiologish und systematisch bearbeitet, 139 pp., 1849.

Not, F., Valentin, K., Romari, K., Lovejoy, C., Massana, R., Töbe, K., Vaulot, D., and Medlin, L.: Picobiliphytes, a new marine picoplanktonic algal group with unknown affinities to other eukaryotes, Science, 315, 252-254, 2007.

Not, F., Massana, R., Latasa, M., Marie, D., Colson, C., Eikrem, W., Pedrós-Alió, C., Vaulot, D., and Simon, N.: Late summer community composition and abundance of photosyn- thetic picoeukaryotes in Norwegian and Barents seas, Limnol. Oceanogr., 50, 1677-1686, 2005.

Palenik, B., Brahamsha, B., Larimer, F. W., Land, M., Hauser, L., Chain, P., Lamerdin, J., Regala, W., Allen, E. E., McCarren, J., Paulsen, I., Dufresne, A., Partensky, F., Webb, E. A., and Waterbury, J.: The genome of a motile marine Synechococcus, Nature, 424, 1037-1042, 2003.

Palenik, B., Grimwood, J., Aerts, A., Rouze, P., Salamov, A., Putnam, N., Dupont, C., Jorgensen, R., Derelle, E., Rombauts, S., Zhou, K., Otillar, R., Merchant, S. S., Podell, S., Gaasterland, T., Napoli, C., Gendler, K., Manuell, A., Tai, V., Vallon, O., Piganeau, G., Jancek, S., Heijde, M., Jabbari, K., Bowler, C., Lohr, M., Robbens, S., Werner, G., Dubchak, I., Pazour, G. J., Ren, Q., Paulsen, I., Delwiche, C., Schmutz, J., Rokhsar, D., Van de Peer, Y., Moreau, H., and Grigoriev, I. V.: The tiny eukaryote Ostreococcus provides genomic insights into the paradox of plankton speciation, Proc. Natl. Acad. Sci. USA, 104, 7705-7710, 2007.

Platt, T., Subba-Rao, D. V., and Irwin, B.: Photosynthesis of picoplankton in the oligotrophic ocean, Nature, 300, 701-704, 1983.

Pruesse, E., Quast, C., Knittel, K., Fuchs, B. M., Ludwig, W., Peplies, J., and Glockner, F. O.: SILVA: a comprehensive online resource for quality checked and aligned ribosomal RNA sequence data compatible with ARB, Nucleic Acids Res., 35, 7188-7196, 2007.

Rappé, M. S., Connon, S. A., Vergin, K. L., and Giovannoni, S. J.: Cultivation of the ubiquitous SAR11 marine bacterioplankton clade, Nature, 418, 630-633, 2002.

Rippka, R., Coursin, T., Hess, W., Lichtle, C., Scanlan, D. J., Palinska, K. A., Iteman, I., Partensky, F., Houmard, J., and Herdman, M.: Prochlorococcus marinus Chisholm et al. 1992 subsp. pastoris subsp. nov. strain PCC 9511, the first axenic chlorophyll $a_{2} / b_{2}$-containing cyanobacterium (Oxyphotobacteria), Int. J. Syst. Evol. Microbiol., 50, 1833-1847, 2000.

Rocap, G., Distel, D. L., Waterbury, J. B., and Chisholm, S. W.: Resolution of Prochlorococcus and Synechococcus ecotypes by using $16 \mathrm{~S}-23 \mathrm{~S}$ ribosomal DNA internal transcribed spacer sequences, Appl. Environ. Microbiol., 68, 1180-1191, 2002.

Rocap, G., Larimer, F. W., Lamerdin, J., Malfatti, S., Chain, P., Ahlgren, N. A., Arellano, A., Coleman, M., Hauser, L., Hess, W. R., Johnson, Z. I., Land, M., Lindell, D., Post, A. F., Regala, W., Shah, M., Shaw, S. L., Steglich, C., Sullivan, M. B., Ting, C. S., Tolonen, A., Webb, E. A., Zinser, E. R., and Chisholm, S. W.: Genome divergence in two Prochlorococcus ecotypes reflects oceanic niche differentiation, Nature, 424, 1042-1047, 2003.

Rodríguez, F., Derelle, E., Guillou, L., Le Gall, F., Vaulot, D., and Moreau, H.: Ecotype diversity in the marine picoeukaryote $O s$ treococcus (Chlorophyta, Prasinophyceae), Environ. Microbiol., 7, 853-859, 2005.

Romari, K. and Vaulot, D.: Composition and temporal variability of picoeukaryote communities at a coastal site of the English Channel from 18S rDNA sequences, Limnol. Oceanogr., 49, 784-798, 2004.

Sieburth, J. M., Smetacek, V., and Lenz, J.: Pelagic ecosystem structure: heterotrophic compartments of the plankton and their relationship to plankton size fractions, Limnol Oceanogr, 23, 1256-1263, 1978.

Tamura, K., Dudley, J., Nei, M., and Kumar, S.: MEGA4: Molecular Evolutionary Genetics Analysis (MEGA) Software Version 
4.0, Mol. Biol. Evol., msm092, 2007.

Vaulot, D., Le Gall, F., Marie, D., Guillou, L., and Partensky, F.: The Roscoff Culture Collection (RCC): a collection dedicated to marine picoplankton, Nova Hedwigia, 79, 49-70, 2004.

Waterbury, J. B., Watson, S. W., Guillard, R. R. L., and Brand, L. E.: Wide-spread occurence of a unicellular, marine planktonic, cyanobacterium, Nature, 277, 293-294, 1979.
Zengler, K., Toledo, G., Rappe, M., Elkins, J., Mathur, E. J., Short, J. M., and Keller, M.: Cultivating the uncultured, Proc. Natl. Acad. Sci. USA, 99, 15 681-15 686, 2002.

Zingone, A., Chrétiennot-Dinet, M. J., Lange, M., and Medlin, L.: Morphological and genetic characterization of Phaeocystis cordata and P. jahnii (Prymnesiophyceae), two new species from the Mediterranean Sea, J. Phycol., 35, 1322-1337, 1999. 